\title{
Functional Properties of Gelatin Hydrolysate from Salmon Skin (Salmo salar)
}

\author{
Poh Yi Cheng, Nur 'Aliah Daud and Abdul Salam Babji
}

\author{
School of Chemical Sciences and Food Technology, Faculty of Science and Technology, Universiti \\ Kebangsaan Malaysia, 43600 UKM Bangi, Selangor, Malaysia
}

\begin{abstract}
Gelatin hydrolysate is derived from a hydrolysis of gelatin (denatured collagen) to expose the functional properties of the hydrolysate obtained. This study was carried out to determine functional properties of gelatin hydrolysate from salmon skin as influenced by the degree of enzymatic hydrolysis. Aqueous extraction of gelatin from salmon skin was done at $45^{\circ} \mathrm{C}$ for 60 minutes. The extracted gelatin was then hydrolysed using $1 \%$ alcalase at $54.5^{\circ} \mathrm{C}$ and $\mathrm{pH}$ 8. The functional properties determined were molecular weight, solubility, foaming capacity and stability, emulsifying activity and stability index were analysed. It was found that different time of hydrolysis $(5,15,45$ and 180 minutes) resulted in different degree of hydrolysis $(\mathrm{DH})(10,20,30$ and $40 \%$, respectively). The gelatin hydrolysate at $40 \% \mathrm{DH}$ showed the highest solubility $(\mathrm{p}<0.05)$. However, the foaming and emulsifying properties were the highest at $10 \%$ degree of hydrolysis $(p<0.05)$.
\end{abstract}

Keywords: Gelatin hydrolysate, salmon skin, foaming properties, emulsifying properties.

\section{INTRODUCTION}

According to Food and Agriculture Organization (FAO) in 2006, more than 132 million tonnes of fish was captured every year around the world. From 70$85 \%$ wastes of the processed fish, $30 \%$ of it was skin and bones [1]. Salmon is a healthy source of food protein, and rich in omega-3 fatty acid, vitamin D and good cholesterol [2]. Increasing demand and consumption of salmon in the form of value added product (sushi, sashimi and steak) resulted in salmon skin as waste product.

Interest of recycling the wastes of processed fish is due to a high value of nutrition, a dynamic ability and also have a potential to be used in food system as a binder, an emulsion and a gelling agent. With the rising of technology, these wastes have been processed producing a high quality product. Collagen in bones and skin of animals can produce a high quality gelatin product after denaturation process [3]. Gelatin hydrolysate is produced due to its bioactive peptide which can potentially act as a modulation of physical metabolism, alternative used of fish gelatin [4].

Functional protein's ability can be altered by physical, chemical or enzymatic hydrolysis through changes of protein structure. Enzymatic hydrolysis is much preferred due to average processed condition requirement, easily controlled reaction and yield of wastes is minimum [5]. Enzyme also possess a critical

*Address correspondence to this author at the School of Chemical Sciences and Food Technology, Faculty of Science and Technology, Universiti Kebangsaan Malaysia, 43600 UKM Bangi, Selangor, Malaysia; Tel: +60133357700; Fax: +603-89213232; E-mail: daging@ukm.edu.my point by affecting physicochemical, functional and sensory properties [1]. In hydrolysis process, the breakage of peptide bond will increase concentration of hydrolysates, free amino and carboxyl group of amino acid which may contribute to functional protein properties $[1,5,6]$. The properties involved include protein solubility, water holding capacity, oil holding capacity, emulsion and foaming characteristics [1].

Over the years, many studies have been done on sardine [7], capelin [8], shark protein [9], herring [10], salmon protein [11], soy protein [12] and whey protein [13] which proved that enzymatic hydrolysis had increased functional properties of protein. Research on gelatin hydrolysate from salmon skin at different degree of hydrolysis could be one of an interesting subject to be further studied. Therefore, this study aimed to produce gelatin hydrolysates from salmon skin at different degree of hydrolysis and study the effects on solubility, foaming and emulsion properties.

\section{MATERIALS AND METHODS}

\subsection{Materials}

Salmon skin was obtained in the frozen state from sashimi supplier in Penang, Malaysia. Chemicals used were of analytical grade, purchased from Sigma-Aldrich US.

\subsection{Gelatin Preparation}

Gelatin extraction from salmon skin was carried out according to Kolodziesjka et al. method [14]. The fish skin was cut into small pieces and immersed in $0.45 \mathrm{~N}$ $\mathrm{NaCl}$ solution with ratio $1: 6(\mathrm{w} / \mathrm{v})$ at $4^{\circ} \mathrm{C}$ for 6 minutes. 
The sample was then washed with distilled water. Immersion and washing steps were repeated twice. Sample was filtered with cheese cloth. The skin cake was added with distilled water at ratio 1:10 (w/v) and incubated in waterbath shaker at $45^{\circ} \mathrm{C}, 200 \mathrm{rpm}$ for 60 minutes. The sample was then centrifuged at $10000 \mathrm{xg}$, $15^{\circ} \mathrm{C}$ for 15 minutes. The supernatant was concentrated using a rotary evaporator, then was freeze dried to be keep for further analysis.

\subsection{Gelatin Hydrolysate Preparation}

Gelatin hydrolysate preparation was done according to Yang et al. method [15]. Sample of freeze dried gelatin weighing $2 \mathrm{~g}$ was dissolved in $200 \mathrm{ml} 0.1 \mathrm{M}$ sodium phosphate buffer ( $\mathrm{pH}$ 9.3). The sample was incubated in waterbath at $45^{\circ} \mathrm{C}$ for 5 minutes to dissolve gelatin. The $\mathrm{pH}$ was adjusted to 7.8 and $1 \%$ alcalase enzyme was added to the sample, then incubated in $54.5^{\circ} \mathrm{C}, 100 \mathrm{rpm}$ for 6 hours. The enzyme was inactivated by heat at $95^{\circ} \mathrm{C}$ for 10 minutes. The sample was then freeze dried to prepare gelatin hydrolysate's powder for further analyses. Isolated soy protein (ISP) and extracted gelatin without hydrolysation $\left(G_{0}\right)$ were used as control samples.

\subsection{Degree of Hydrolysis Measurement [16]}

Hydrolysed gelatin solution was prepared by mixing gelatin hydrolysate powder with distilled water $(1 \mathrm{mg} / \mathrm{ml})$. Then, $0.5 \mathrm{ml}$ of the solution was mixed with $2.0 \mathrm{ml} 1 \%$ sodium dodecyl sulphate (SDS). From the mixture, $0.125 \mathrm{ml}$ was mixed with $2.0 \mathrm{ml}$ sodium phosphate buffer $(0.2 \mathrm{M}, \mathrm{pH} 8.2)$ and $1.0 \mathrm{ml}$ of $0.01 \%$ TNBS solution. This mixture was then in a water bath at $50^{\circ} \mathrm{C}$ for 30 minutes. The reaction was terminated by adding $2.0 \mathrm{ml}$ of $0.1 \mathrm{~N}$ sodium sulfite and allowed to cool at room temperature for 30 minutes. The degree of hydrolysis (DH) was determined using spectrophotometer (Shimadzu, Model UV-2450) at 420 $\mathrm{nm}$. DH was calculated by using the following formula:

$\mathrm{DH}(\%)=100 \times\left(\mathrm{A}_{\text {sample }}-\mathrm{A}_{\text {control }} / \mathrm{A}_{\mathrm{TGH}}-\mathrm{A}_{\text {control }}\right)$

Where,

$A_{\text {sample: }}$ : sample absorption; $A_{\text {control }}$ : control absorption;

$\mathrm{A}_{\mathrm{TGH}}$ : total hydrolysed gelatin absorption

\subsection{Molecular Weight Determination}

Molecular weights of extracted gelatin and gelatin hydrolysates were determined using SDS-PAGE. The analysis was done in two parts, glycine and tricine system. The glysin system was done to measure the molecular weight of a wide range of sizes while the tricine system was to measure the molecular weight of polypeptide. SDS-PAGE was performed following the method described by Laemmli [17]. In glycine system, $12 \%(\mathrm{w} / \mathrm{v})$ separating gel and $4 \%(\mathrm{w} / \mathrm{v})$ stacking gel were used. In tricine system, $16 \%$ (w/v) separating gel and $5 \%(\mathrm{w} / \mathrm{v})$ stacking gel were used.

\subsection{Protein Content Determination}

Protein content was determined using Kjeldahl method [18]. Approximately $1 \mathrm{~g}$ of each sample was digested using $12 \mathrm{ml}$ of concentrated sulfuric acid, $7 \mathrm{~g}$ of potassium sulfate and copper in a digestion flask. The mixtures was then heated at $350^{\circ} \mathrm{C}-400^{\circ} \mathrm{C}$ until white smoke appeared $60-90$ minutes. The flask was cooled and added with $75 \mathrm{ml}$ distilled water. The mixture was then neutralised using $40 \%$ sodium hydroxide solution. Nitrogen in the form of ammonia was separated from the digestion mixture by distillation and the ammonia released was steam-trapped with 15 $\mathrm{ml} \mathrm{4 \%} \mathrm{boric} \mathrm{acid} \mathrm{containing} \mathrm{methyl} \mathrm{bromochrome} \mathrm{red}$ and green. The solution was titrated with $0.1 \mathrm{~N} \mathrm{HCl}$ until the end point. Calculation of nitrogen content is as follows:

$\mathrm{mg}$ of $\mathrm{N} / \mathrm{g}$ of sample=

$\frac{* \mathrm{HCl}(\mathrm{ml}) \mathrm{xN} \text { standard acid x } 0.014}{\text { sample weight }} \times 1000$

${ }^{*} \mathrm{~mL}$ of hydrochloric acid required for titrating sample solution

Protein $(\%)$ of sample $=\mathrm{N}(\mathrm{mg}) \times 6.25 \times 100$

\subsection{Functional Properties Analysis}

\subsubsection{Protein Solubility}

Protein solubility was determined according to Klompong et al. method [19] by dissolving $0.125 \mathrm{~g}$ sample in $25 \mathrm{ml}$ of deionized water. $\mathrm{pH}$ was adjusted to

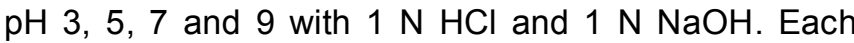
mixture was stirred at room temperature for 30 minutes, then centrifuged at $15000 \mathrm{rpm}$ for 15 minutes. Protein content in the supernatant was determined by Kjeldahl method [18]. The protein solubility was determined using the following formula:

Protein solubility $(\%)=($ protein content in supernatant $/$ protein content in the sample) $\times 100$ 


\subsubsection{Foaming Capacity and Stability}

Foaming capacity and stability of gelatin hydrolysates at different degrees of hydrolysis $(10,20$, 30 and $40 \%)$ and ph (3, 5, 7 and 9$)$ were determined by the method of Shahidi et al. [8]. The samples were prepared at $0.5 \%(\mathrm{w} / \mathrm{v})$ using distilled water and homogenized (Ultra Turrax Ika T 25) at 16000 rpm for 1 minute. The total volume of foam was determined after $0,0.5,1,5$ and 10 minutes. Foaming capacity was calculated by the formula below:

Foaming capacity $(\%)=(A-B) / B \times 100$

Where,

$A=$ volume after foaming

$B=$ volume before foaming

Foaming stability $(\%)=(A-B) / B \times 100$

Where,

$A=$ volume after foaming were placed for 30 minutes

$B=$ volume before foaming

\subsubsection{Emulsification Properties}

Emulsifying properties were determined by Pearce and Kinsella method [20]. Approximately $0.15 \mathrm{~g}$ of each sample was dissolved in $30 \mathrm{ml}$ distilled water and $10 \mathrm{ml}$ of soy oil. $\mathrm{pH}$ of the mixture was adjusted to $\mathrm{pH} 3,5,7$ and 9. The mixture was homogenized at $20000 \mathrm{rpm}$ for 1 minute. Then, $50 \mu \mathrm{l}$ of the total mixture was pipetted out at 0 and 10 minutes, mixed with $5 \mathrm{ml} 0.1 \%$ SDS and the absorbance was measured at $500 \mathrm{~nm}$ using a spectrophotometer (Shimadzu, Model UV-2450).

Emulsifying activity index (EAI) $\left(\mathrm{m}^{2} / \mathrm{g}\right)=(2 \times 2303 \times \mathrm{A})$ $/(0.25 \times$ protein weight, $g)$

Where,

$A=$ absorption at $500 \mathrm{~nm}$

Emulsification stability index $(E S I)(\min )=\left(\mathrm{A}_{\mathrm{o}} \times \Delta_{\mathrm{t}}\right) / \Delta_{\mathrm{A}}$

Where,

$\Delta_{\mathrm{t}}=10$ minutes

$\Delta_{\mathrm{A}}=\mathrm{A}_{\mathrm{o}}-\mathrm{A}_{10}$, absorption after 10 minutes and 0 minutes at $500 \mathrm{~nm}$.

\subsection{Statistical Analysis}

All data were analyzed using SAS software (version 6.12) using one-way Analysis of Variance (ANOVA) and Duncan Multiple Range Difference Test to determine whether there were significant differences between the samples. Significant level was set at $p$ $<0.05$. All experiments were carried out in triplicates.

\section{RESULTS AND DISCUSSION}

\subsection{Degree of Hydrolysis}

Based on preliminary data (results not shown), it was found that hydrolysates of salmon skin gelatin with different degrees of hydrolysis, 10, 20, 30 and $40 \%$ were produced at $5,15,45$ and 180 minutes,

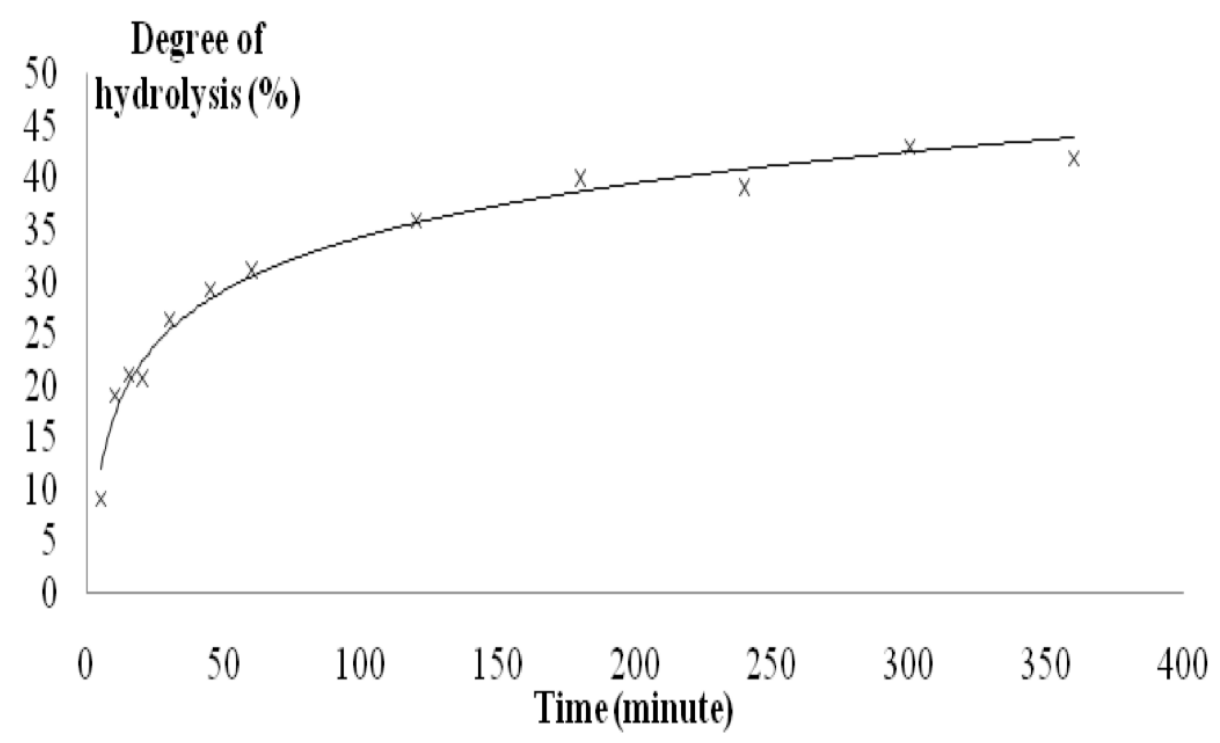

Figure 1: Degree of hydrolysis of salmon skin gelatin hydrolysate for 6 hours. 
respectively. Figure 1 shows the hydrolysis curve of gelatin that exhibited typical curves. The profile of the degree of hydrolysis obtained from this study is similar to the classical hydrolysis of proteins induced by protease [21].

\subsection{Molecular Weight}

Based on the results of glycine system, molecular weight of all gelatin hydrolysates were less than 21.5 $\mathrm{kDa}$ regardless the degree of hydrolysis. Thus, SDSPAGE tricine system was used to determine the molecular weights of the hydrolysates. Figure $\mathbf{2}$ showed the molecular weight distribution from tricine system. It was found that hydrolysed gelatin at 10,20 and $30 \% \mathrm{DH}$ was in the range of 26.6-6.5, 17.0-6.5 and 14.4-6.5 kDa, respectively. However, at $40 \% \mathrm{DH}$, there was no clear band observed, probably due to complete hydrolysis of the gelatin.

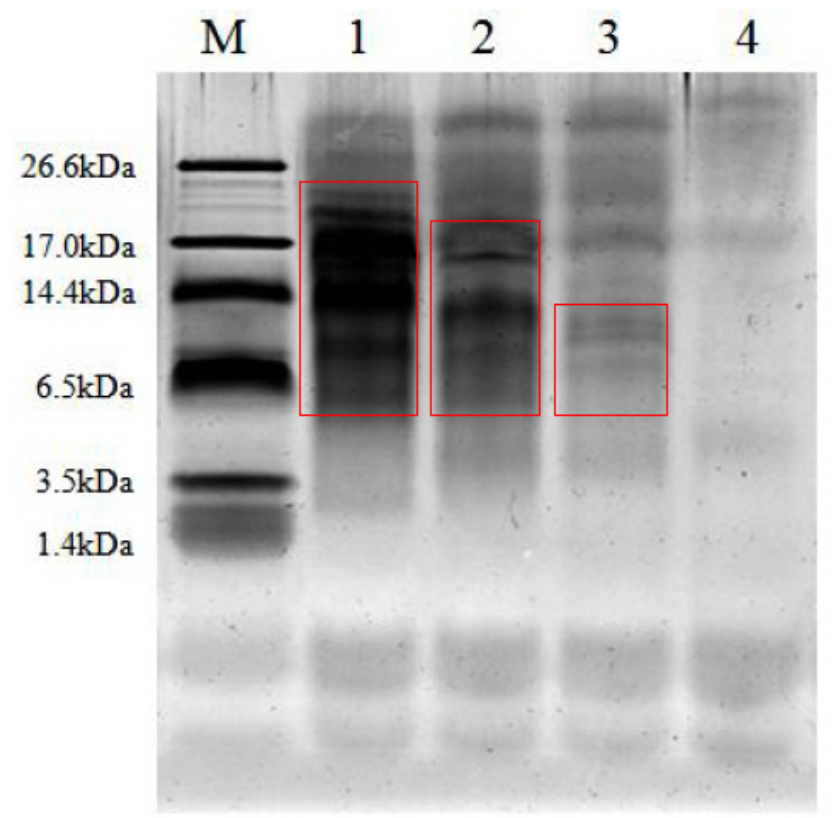

Figure 2: SDS-PAGE trisin system. M: standard; 1: $\mathrm{D}_{\mathrm{H}} 10 \%$; 2: $\mathrm{D}_{\mathrm{H}} 20 \% ; 3: \mathrm{D}_{\mathrm{H}} 30 \% ; 4: \mathrm{D}_{\mathrm{H}} 40 \%$.

According to Gbogouri et al. [21], the low molecular weight of peptide at high $\mathrm{DH}$ have higher peptides polarity. Subsequently, it forms strong hydrogen bonding with water molecule which makes the peptides more soluble, compared to polypeptides with higher molecular weight at low $\mathrm{DH}$. For foaming activity, the presence of a surface active species (surfactant) that adsorbs at the bubble surface reduces the surface energy or interfacial tension, necessary for the formation of foam [22], [23]. Low molecular weight of peptides adsorb at the air-water interface rapidly in comparison to much larger protein molecules. For a protein to have good emulsion property, it has to have low molecular weight, a balance charge of amino acid composition and high solubility properties [24].

\subsection{Solubility of Protein}

It was observed that gelatin hydrolysates with different degree of hydrolysis display protein solubility from $20 \%$ and above. Gelatin hydrolysates with different degree of hydrolysis had higher protein solubility compared to isolated soy protein (ISP). Gbogouri et al. [21] showed that salmon hydrolysates has higher solubility with higher degree of hydrolysis, which is similar as the results obtained in this study. At higher degree of hydrolysis, the peptides have a higher polarity and can form stronger hydrogen bonds with water when compared to the polypeptide present in the gelatin or hydrolysates with low degree of hydrolysis. It was found that the hydrolysed gelatin has the lowest protein solubility at $\mathrm{pH} 5(\mathrm{p}<0.05)$ (Figure 3$)$. These data indicate that hydrolysed gelatin with high molecular weight will precipitate at $\mathrm{pH}$ approaching the isoelectric point $(\mathrm{pl})$ after the hydrolysis of protein. At $\mathrm{pH}$ values below or above $\mathrm{pl}$ of the protein the solubility increases due to repelling of the positive or negative ions, as well as due to increased interaction of the charged polypeptide chains with water dipoles [25]. Protein solubility plays an important role in the functional properties of gelatin hydrolysates such as foaming and emulsification properties due to the rapid migration and adsorption of peptides between the surfaces [26].

\subsection{Foaming Capacity and Stability}

Protein hydrolysates led to a decrease in surface tension between water and air space, causing the existence of foaming capacity [9]. Foaming capacity and foaming stability of gelatin hydrolysates at different degrees of hydrolysis was lower than ISP and gelatin, $(p<0.05)$ as shown in Figures 4 and $\mathbf{5}$, respectively. It was found that hydrolysed gelatin with higher degree of hydrolysis has lower foaming capacity. Gelatin with 10 and $20 \%$ degree of hydrolysis showed foaming activity and stability but the foam start to decrease at 30 and $40 \%$ of degree of hydrolysis. Klompong et al. [19] reported that the foaming capacity for protein hydrolysates from capelin fish is also less at high degree of hydrolysis. This phenomenon is caused by the lack of alignment of small peptides on the surface of water and air [27]. According to Zhu and Damodaran [28], the addition of ions such as $\mathrm{Ca}^{2+}$ or $\mathrm{Mg}^{2+}$ might cause unfolding and polymerization of the proteins at 


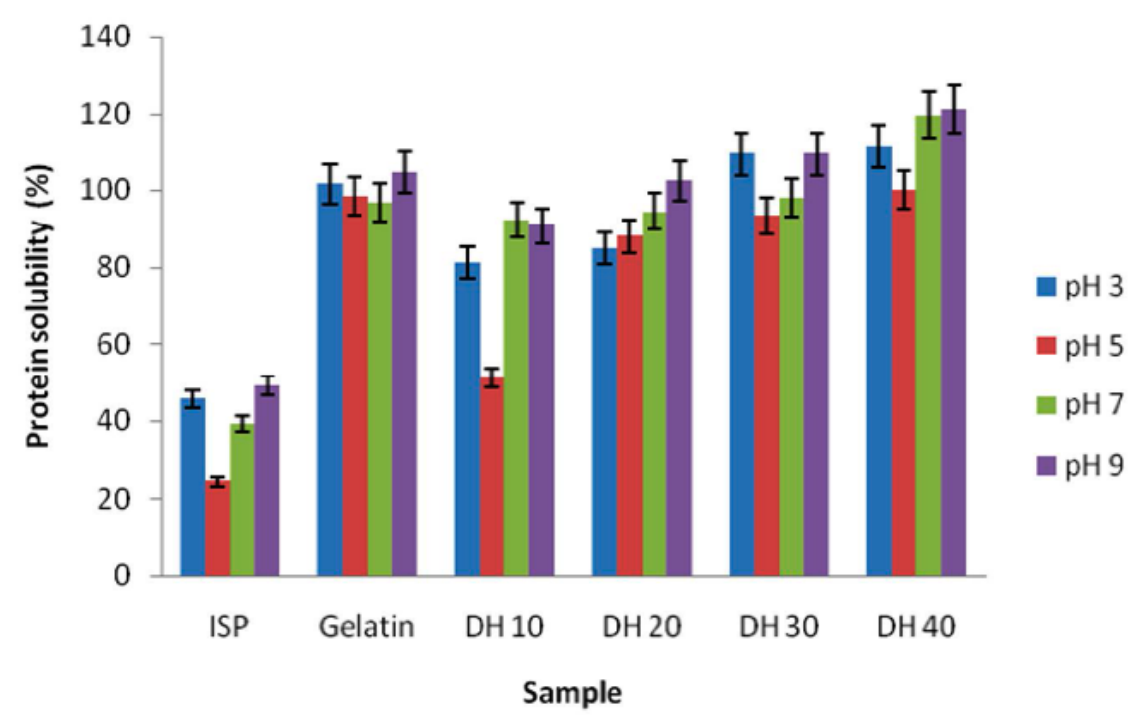

Figure 3: Protein solubility for gelatin hydrolysate at $10-40 \%$ degree of hydrolysis, $\mathrm{pH} 3-9$.

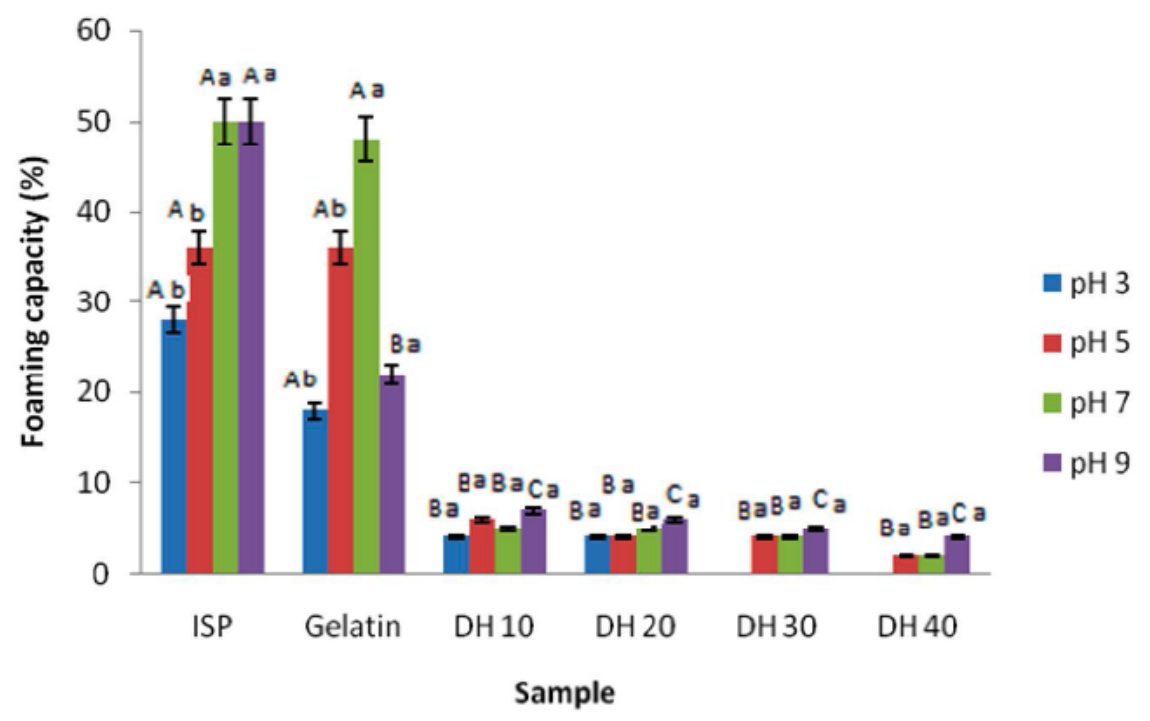

Figure 4: Foaming capacity at 10 minutes for gelatin hydrolysate, 10-40\% degree of hydrolysis, $\mathrm{pH}$ 3-9. Different capital letters indicate significant differences $(P<0.05)$ of hydrolysates with different sample. Different lowercase letters indicate significant differences $(P<0.05)$ of hydrolysates with different $\mathrm{pH}$.

the interface via ionic linkages so that the foaming can be improved.

Foaming capacity was left for 30 minutes to observe the foaming stability. The stability and strength of the foam, measured by the rate of drainage and the resistance to compression, respectively, depend on the flexibility and the rheological properties of the film. The results show gelatin hydrolysates at high degrees of hydrolysis has low foaming stability. Foaming stability is dependent on the nature of the film and limit the interaction between proteins in the matrix. Foaming stability can be enhanced by flexible proteins that increase protein concentration and film thickness [29].
Thus, gelatin hydrolysates with a low molecular weight are unable to maintain proper orientation of molecules on the surface.

\subsection{Emulsification Properties}

Emulsifying activity index (EAl) and emulsifying stability index (ESI) gelatin hydrolysate produced by enzymatic hydrolysis alcalase at different degrees at $\mathrm{pH}$ (3-9) are shown in Figures 6 and 7, respectively. Both are determined based on emulsion turbidity at a wavelength of $500 \mathrm{~nm}$ [20]. Hydrolysed gelatin with a high degree of hydrolysis has low EAI and ESI due to the size of small peptides $(p<0.05)$. According to 


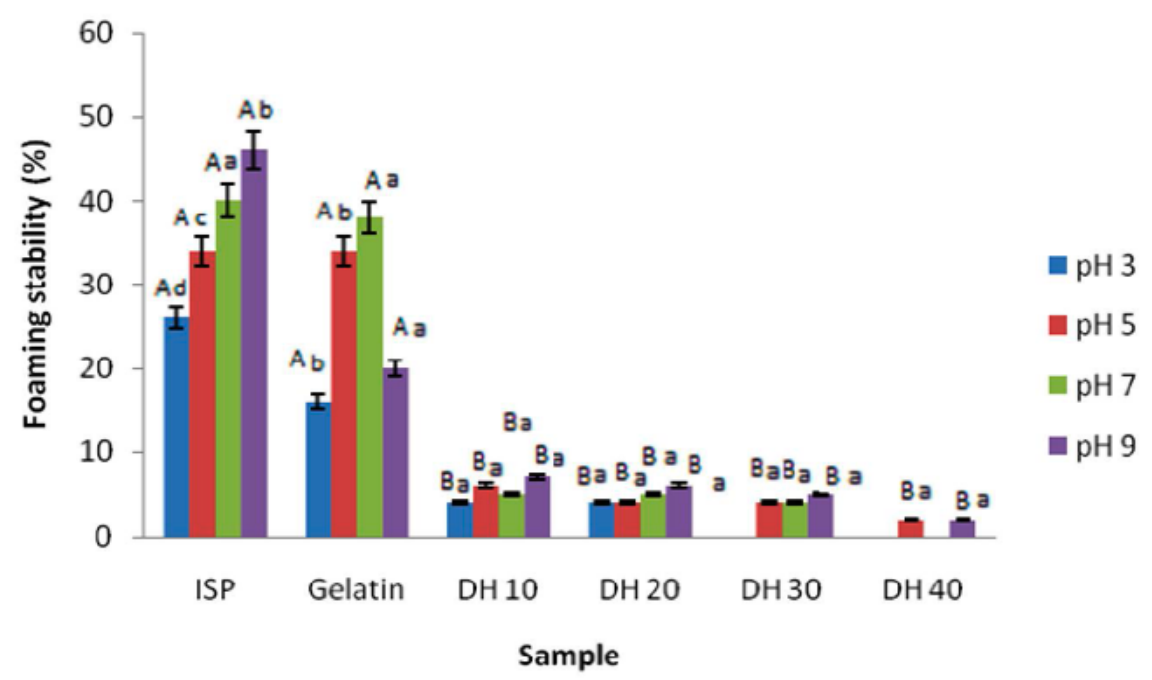

Figure 5: Foaming stability for gelatin hydrolysate at $10-40 \%$ degree of hydrolysis, $\mathrm{pH} 3-9$.

Different capital letters indicate significant differences $(P<0.05)$ of hydrolysates with different sample.

Different lowercase letters indicate significant differences $(P<0.05)$ of hydrolysates with different $\mathrm{pH}$.

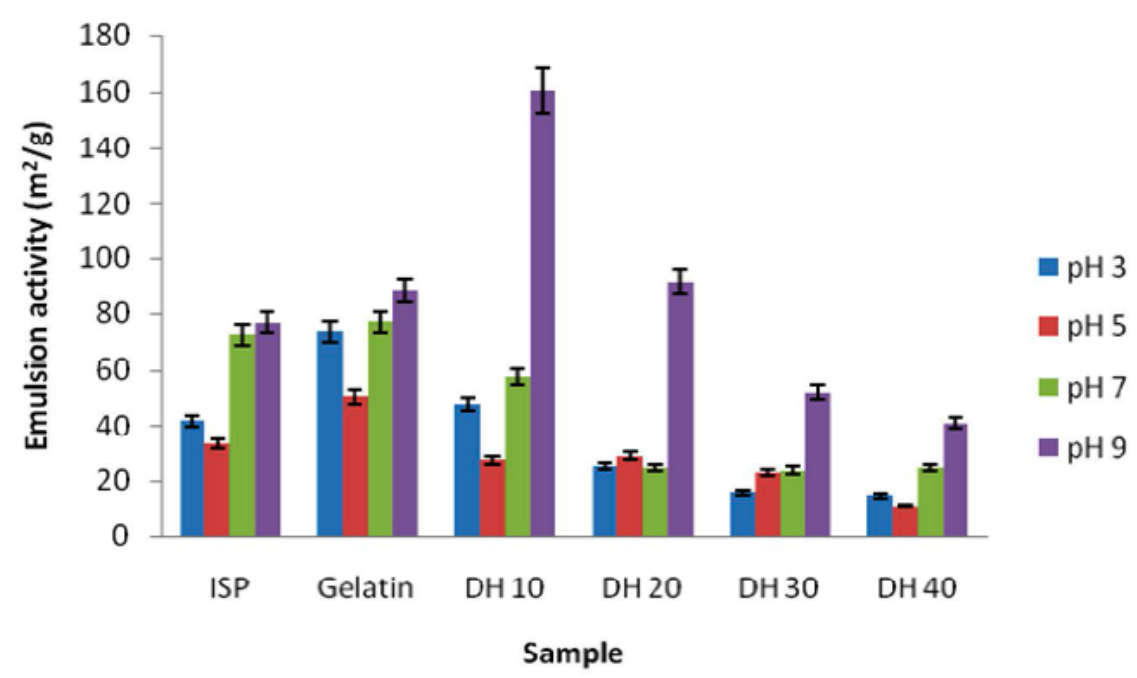

Figure 6: Emulsification activity index for gelatin hydrolysate at 10-40\% degree of hydrolysis, $\mathrm{pH} 3-9$.

Klompong et al. [19], protein hydrolysates from the yellow stripe fish showed lower both EAI and ESI properties when the degree of hydrolysis increases. At a lower degree of hydrolysis of $10 \%$, hydrolysed gelatin showed strong emulsifying properties compared to the degree of hydrolysis $40 \%(p<0.05)$.

The peptides with higher molecular weight or more hydrophobic will contribute to the stability of emulsification [30]. EAI and ESI values increased when the $\mathrm{pH}$ is away from $\mathrm{pH} 5$. These effects result from amino acid sequence and composition of the various charges which was brought at a certain $\mathrm{pH}$. The efficiency of proteins as emulsifiers depends upon their surface hydrophobicity and charge, stearic effects, elasticity or rigidity, and viscosity in solution. The $\mathrm{pH}$ of the environment affects the emulsifying properties by changing the solubility and surface hydrophobicity of proteins, as well as the charge of the protective layer around the lipid globules. Ions may alter the electrostatic interactions, conformation, and solubility of the proteins [25].

\section{CONCLUSION}

High solubility of protein hydrolysates obtained showed a potential on functional properties of gelatin hydrolysate. Gelatin hydrolysates from salmon skin demonstrated lower foaming ability compared to ISP $(\mathrm{R})$ and gelatin $(\mathrm{C})$. Higher $\mathrm{DH}$ resulted in lower foaming stability. Gelatin hydrolysate produced at lower $\mathrm{DH}$ is more suitable for emulsifying properties, 


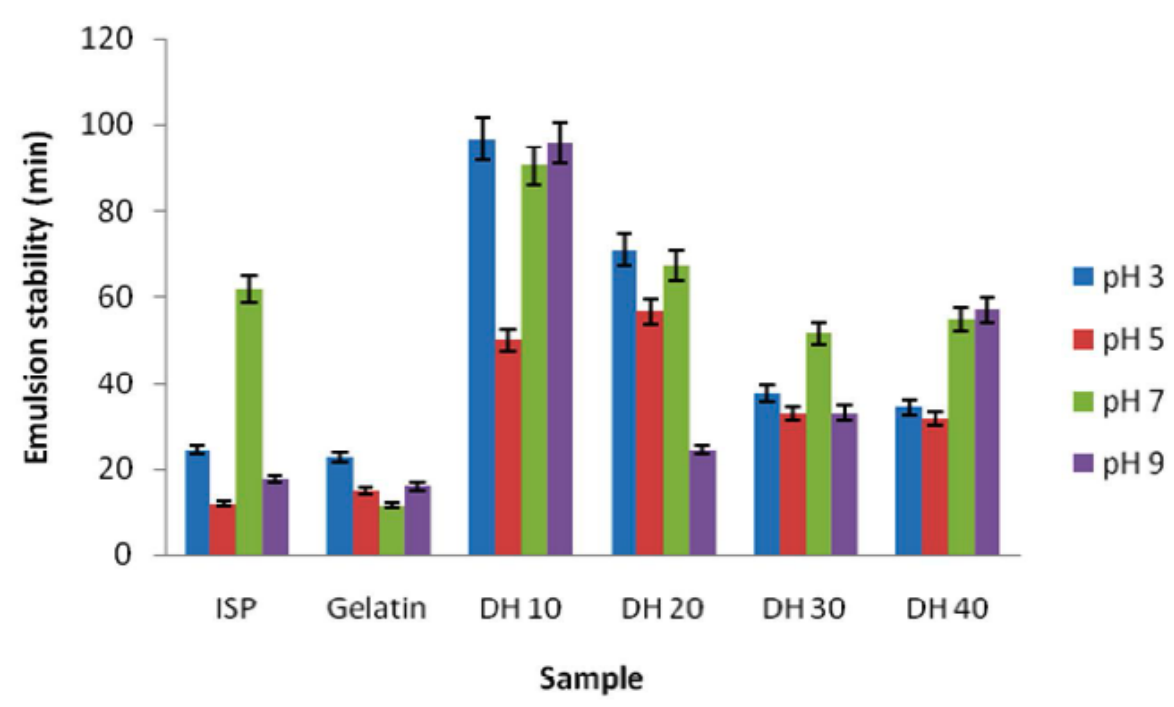

Figure 7: Emulsification stability index for gelatin hydrolysate at 10-40\% degree of hydrolysis, $\mathrm{pH} 3-9$.

compared to the higher DH. Gelatin and gelatin hydrolysates at lower $\mathrm{DH}$ illustrated the potential of peptide surfactants in improvement of foaming and emulsifying properties. Foaming is responsible for desirable rheological properties of many foods, such as texture of bread, cakes, whipped cream and ice cream. Emulsifying properties of protein is important for food products, mainly like comminuted meat batters, to form a continuous phase of emulsion. This new foaming and emulsifying agents may contribute towards improvement of food ingredients and food products.

\section{REFERENCES}

[1] Wasswa J, Tang J, Gu X, Yuan X. Influence of the extent of enzymatic hydrolysis on the functional properties of protein hydrolysate from grass carp (Ctenopharngodon idella) skin. Food Chemistry 2007; 104: 1698-1704. http://dx.doi.org/10.1016/j.foodchem.2007.03.044

[2] Zague V. A new view concerning the effects of collagen hydrolysate intake on skin properties. Arch Dermatol Res 2008; 300: 479-483. http://dx.doi.org/10.1007/s00403-008-0888-4

[3] Choi SS, Regenstein JM. Physico-chemical and sensory characteristics of fish gelatin. Journal of Food Science 2000; 65: 194-199.

http://dx.doi.org/10.1111/j.1365-2621.2000.tb15978.x

[4] Phanturat P, Benjakul S, Visessanguan W, Roytrakul S. Use of pyloric caeca extract from bigeye snapper (Priacanthus macracanthus) for the production of gelatin hydrolysate with antioxidative activity. LWT - Food Science and Technology 2010; 43 (1): 86-97. http://dx.doi.org/10.1016/j.Iwt.2009.06.010

[5] Liu Q, Kong B, Xiong YL, Xia X. Antioxidant activity and functional properties of porcine plasma protein hydrolysate as influenced by the degree of hydrolysis. Food Chemistry 2010; 118: 403-410. http://dx.doi.org/10.1016/j.foodchem.2009.05.013

[6] Spellman D, McEvoy E, O'Cuinn G, FitzGerald RJ. Proteinase and exopeptidase hydrolysis of whey protein: Comparison of the TNBS, OPA and $\mathrm{pH}$-stat methods for quantification of degree of hydrolysis. International Dairy Journal 2003; 13: 447-453.

http://dx.doi.org/10.1016/S0958-6946(03)00053-0

[7] Quaglia GB, Orban E. Influence of enzymatic hydrolysis on structure and emulsifying properties of sardine (Sardina pilchardus) protein hydrolysate. Journal of Food Science 1990; 55: 1571-1573.

http://dx.doi.org/10.1111/j.1365-2621.1990.tb03571.x

[8] Shahidi F, Xiao-Quing $\mathrm{H}$, Synowiecki J. Production and characteristics of protein hydrolysates from capelin (Mallotus villosus). Food Chemistry 1995; 53: 285-293. http://dx.doi.org/10.1016/0308-8146(95)93934-J

[9] Diniz FM, Martin AM. Effects of the extent of enzymatic hydrolysis on functional properties of shark protein hydrolysate. Lebensmittel-Wissenschaftund-Technologie 1997; 30: 266-272.

http://dx.doi.org/10.1006/fstl.1996.0184

[10] Sathivel S, Bechtel PJ, Crapo S, Reppond KD, Prinnyawiwatkul W. Biochemical and functional properties of herring (Clupea harengus). Journal of Food Science 2003; 68: 2196-2200.

http://dx.doi.org/10.1111/j.1365-2621.2003.tb05746.x

[11] Sathivel S, Smiley S, Prinyawiwatkul W, Bechtel PJ. Functional and nutritional properties of red salmon (Oncorhynchus nerka) enzymatic hydrolysates. Journal of Food Science 2005; 70(6): 401-406. http://dx.doi.org/10.1111/j.1365-2621.2005.tb11437.x

[12] Jung S, Murphy PA, Johnson LA. Physicochemical and functional properties of soy protein substrates modified by low levels of protease hydrolysis. J Food Sci 2005; 70: C180C187.

[13] Sinha R, Radha C, Prakash J, Kaul P. Whey protein hydrolysate: functional properties, nutritional properties and utilization in beverage formulation. Food Chemistry 2007; 101(4): 1484-1491.

http://dx.doi.org/10.1016/.j.foodchem.2006.04.021

[14] Kolodziejska I, Skierka E, Sadowska M, Kolodziejski W, Niecikowska C. Effect of extracting time and temperature on yielding of gelatin from different fish offal. Food Chemistry 2008; 107: 700-706.

http://dx.doi.org/10.1016/j.foodchem.2007.08.071

[15] Yang JI, Ho HY, Chu YJ, Chow CJ. Characteristic and antioxidative activity of retorded gelatin hydrolysate from cobia (Rachycentron canadum) skin. Food Chemistry 2008; 110: 128-136. http://dx.doi.org/10.1016/j.foodchem.2008.01.072 
[16] Adler-Nissen J. Determination of the degree of hydrolysis of food protein hydrolysate by trinitrobenzenesulfonic acid. Journal of Agricultural and Food Chemistry 1979; 27: 12561262.

http://dx.doi.org/10.1021/jf60226a042

[17] Laemmli UK. Cleavage of structural proteins during the assembly of the head of bacteriophage T4. Nature 1970; 227: 680-685. http://dx.doi.org/10.1038/227680a0

[18] AOAC. Official Methods of Analysis. 2nd Ed. Washington D. C.: Association of Official Analytical Chemists 1990.

[19] Klompong V, Benjakul S, Kantachote D, Shahidi F. Antioxidative activity and functional properties of protein hydrolysate of yellow stripe trevally (Selaroides leptolepis) as influenced by the degree of hydrolysis and enzyme type. Food Chemistry 2007; 102: 1317-1327. http://dx.doi.org/10.1016/j.foodchem.2006.07.016

[20] Pearce KN, Kinsella JE. Emulsifying properties of proteins: Evaluation of a turbidimetric technique. Journal of Agricultural and Food Chemistry 1978; 26: 716-723. http://dx.doi.org/10.1021/jf60217a041

[21] Gbogouri GA, Linder M, Fanni J, Parmentier M. Influence of hydrolysis degree on the functional properties of salmon byproduct hydrolysates. Journal of Food Science 2004; 69: 615-622.

http://dx.doi.org/10.1111/j.1365-2621.2004.tb09909.x

[22] Weaire D, Hutzler S. The Physics of Foams, Oxford University Press, Oxford; 1999.
[23] Manev ED, Nguyen AV. Effects of surfactant adsorption and surface forces on thinning and rupture of foam liquid films. Int $\mathrm{J}$ of Mineral Processing 2005; 77: 45. http://dx.doi.org/10.1016/j.minpro.2005.01.003

[24] Belitz HD, Grosch W, Schieberle P. Protein. Food Chemistry. Heidelberg: Springer; 2009.

[25] Sikorski ZE. Chemical and functional properties of food components. Taylor, Francis Group: CRC Press; 2007.

[26] Chobert JM, Bertrand-Harb C, Nicolus MG. Solubility and emulsifying properties of caseins and whey proteins modified enzymatically by trypsin. Journal of Agricultural and Food Chemistry 1988; 36: 674-677.

[27] Nalinanon S, Benjakul S, Visessanguan W, Kishimura $H$. Improvement of gelatin extraction from bigeye snapper skin using pepsinaided process in combination with protease inhibitor. Food Hydrocolloids 2008; 22 (4): 615-622. http://dx.doi.org/10.1016/j.foodhyd.2007.01.012

[28] Zhu H, Damodaran S. Effects of calcium and magnesium ions on aggregation of whey protein isolate and its effect on foaming properties. J Agric Food Chem 1994; 42: 856. http://dx.doi.org/10.1021/jf00040a003

[29] Phillips LG, Whitehead DM, Kinsella JE. Protein stabilized foams. Structure-function of Food Proteins. New York: Academic Press; 1994.

[30] Multilangi WAM, Panyam D, Kilara A. Functional properties of hydrolysates from proteolysis of heat-denatured whey protein isolate. Journal of Food Science 1996; 61: 270-274. http://dx.doi.org/10.1111/j.1365-2621.1996.tb14174.x 